\title{
OPEN Diffusion-weighted MRI for predicting treatment response in patients with nasopharyngeal carcinoma: a systematic review and meta-analysis
}

\author{
Min Kyoung Lee ${ }^{1}$, Yangsean Choi ${ }^{2 \bowtie}$ \& So-Lyung Jung ${ }^{1}$
}

Early prediction of treatment response in nasopharyngeal carcinoma is clinically relevant for optimizing treatment strategies. This meta-analysis was performed to evaluate whether apparent diffusion coefficient (ADC) from diffusion-weighted imaging (DWI) can predict treatment response of patients with nasopharyngeal carcinoma. A systematic search of PubMed-MEDLINE and Embase was performed to identify relevant original articles until July 22, 2021. We included studies which performed DWI for predicting locoregional treatment response in nasopharyngeal carcinoma treated with neoadjuvant chemotherapy, definitive chemoradiation, or radiation therapy. Hazard ratios were meta-analytically pooled using a random-effects model for the pooled estimates of overall survival, local relapse-free survival, distant metastasis-free survival and their $95 \% \mathrm{Cls}$. ADC showed a pooled sensitivity of $87 \%$ (95\% Cl 72-94\%) and specificity of $70 \%(95 \% \mathrm{Cl} 56-80 \%)$ for predicting treatment response. Significant between-study heterogeneity was observed for both pooled sensitivity $\left(I^{2}=68.5 \%\right)$ and specificity $\left(I^{2}=92.2 \%\right)(P<0.01)$. The pooled hazard ratios of low pretreatment ADC for assessing overall survival, local relapse-free survival, and distant metastasis-free survival were 1.42 (95\% Cl 1.09-1.85), 2.31 (95\% Cl 1.42-3.74), and 1.35 (95\% Cl 1.05-1.74), respectively. In patients with nasopharyngeal carcinoma, pretreatment ADC demonstrated good predictive performance for treatment response.

Nasopharyngeal cancer (NPC) is a common subtype of head-and-neck cancers prevalent in Asia and Africa, with about 129,000 new cases reported in $2018^{1}$. NPC is widely treated using intensity-modulated radiotherapy and/or chemotherapy. Although early-stage NPC is adequately treated using radiotherapy alone, chemotherapy is required for locoregionally advanced disease ${ }^{1}$. However, patients with locoregionally advanced NPC have a high probability of recurrence with poor prognosis, even after chemoradiotherapy ${ }^{2}$. Thus, early prediction of treatment response and identification of patients with treatment resistance are clinically relevant for individualized treatment planning.

The International Union Against Cancer/American Joint Committee on Cancer TNM staging system is used to classify NPC $\mathrm{NP}^{3}$ Because of the superior soft-tissue resolution and diagnostic performance in the T stage compared to other modalities, MRI is the imaging modality of choice for primary tumor evaluation ${ }^{4}$. Furthermore, MRI is valuable for tumor staging and post-treatment tumor response evaluation.

However, conventional MRI has limitations regarding the early prediction of treatment response in NPC ${ }^{5}$. Advanced imaging techniques, including DWI and perfusion imaging, are usually applied for the evaluation of treatment response and residual or recurred tumor ${ }^{6}$. Importantly, DWI is a common imaging technique for assessing tissue microstructure by measuring tissue water diffusivity ${ }^{7}$. The ADC, a quantitative parameter calculated from DWI, reflects tumor microstructure, and pretreatment ADC has shown promise in tumor staging and predicting treatment respons $\mathrm{e}^{8-10}$. The benefits of DWI for predicting treatment response and prognosis in NPC have been reported ${ }^{5,6,9,11-19}$; however, the reported sensitivities and specificities were variable. Thus, the current study sought to bridge the gap in the available literature.

${ }^{1}$ Department of Radiology, Yeouido St. Mary's Hospital, College of Medicine, The Catholic University of Korea, Seoul, Republic of Korea. 'Department of Radiology, Seoul St. Mary's Hospital, College of Medicine, The Catholic University of Korea, Seoul, Republic of Korea. ${ }^{\circledR}$ email: phillipchoi007@gmail.com 
The purpose of this systematic review and meta-analysis was to assess the predictive performance of pretreatment ADC for treatment response in patients with NPC.

\section{Materials and methods}

This systematic review and meta-analysis was conducted according to the Preferred Reporting Items for Systematic Reviews and Meta-Analyses (PRISMA) guidelines ${ }^{20}$. The institutional review board of our institution approved this study.

Literature search strategy. A search of the PubMed-MEDLINE and EMBASE databases was performed to identify relevant original articles on the use of DWI MRI for predicting locoregional treatment response in NPC treated with neoadjuvant chemotherapy, definitive chemoradiation therapy, or radiation therapy up until July 22, 2021. The following search terms were used: [(nasopharyngeal)] AND [(carcinoma) OR (carcinomas) OR (cancer) OR (cancers) OR (squamous cell carcinoma)] AND [(chemoradiation) OR (chemoradiotherapy) OR (radiotherapy) OR (radiation therapy)] AND [(“diffusion weighted") OR ("diffusion-weighted") OR (dwmri) OR (DWI) OR ("apparent diffusion coefficient") OR (ADC) OR ("intravoxel incoherent motion") OR (IVIM)]. Only studies published in English were included. We defined 'predictive' as a biomarker of the treatment response to therapy and 'prognostic' as a biomarker of the final survival outcome ${ }^{21}$. The search was limited to studies involving human patients. The bibliographies of the selected articles were further screened to identify other potentially relevant articles.

Inclusion and exclusion criteria. The inclusion criteria were: (1) population: patients with histologically proven NPC who underwent neoadjuvant chemotherapy, definitive chemoradiation, or radiation therapy; (2) index test: DWI MRI with provision for pretreatment ADC of primary NPC; (3) reference standard: the reference standards of the treatment outcome as determined by histology, clinical/imaging follow-up, or a combination of these; (4) outcomes: locoregional failure after neoadjuvant chemotherapy, definitive chemoradiation, or radiation therapy reported in sufficient detail; and (5) study design: all observational studies (retrospective or prospective).

The exclusion criteria were: (1) case reports, review articles, editorials, letters, and conference abstracts; (2) insufficient data on locoregional failure and control; (3) did not provide ADC values of primary NPC; (4) insufficient detail to produce $2 \times 2$ tables; and (5) overlapping patients and data. For population overlap, the study with the larger cohort was included. Two reviewers (blinded and blinded) independently selected appropriate study reports using a standardized form. Disagreement was resolved by reaching a consensus after discussion with a third reviewer (blinded).

Data extraction. The following information was extracted into a standardized form: (1) study characteristics: first author, year of publication, affiliation, patient enrollment period, number of patients, and study design; (2) clinical information: age, cancer stages, endpoints, treatment, criteria for treatment response, and follow-up period; and (3) MRI acquisition parameters: manufacturer, model, tesla, time repetition, time echo, field of view, matrix, b-values, ADC threshold values, ADC change between treatment, and method of delineating region of interest.

Quality assessment. Two reviewers (blinded and blinded) with seven years of experiences in the head and neck diagnostic radiology independently extracted the data and performed a quality assessment. The included studies were evaluated using the Quality Assessment of Diagnostic Accuracy Studies-2 (QUADAS-2) criteria ${ }^{22}$ for predictive studies and Quality in Prognosis Studies (QUIPS) for prognostic studies ${ }^{23}$. Data extraction and quality assessment were performed independently by two reviewers (blinded and blinded). Any disagreement was resolved by a consensus.

Data synthesis and statistical analyses. Using random-effects modeling, pooled sensitivity and specificity with $95 \%$ CIs were generated from individual predictive studies; similarly, pooled overall survival (OS), local relapse-free survival (LRFS), and distant metastasis-free survival (DMFS) with 95\% CIs were generated from prognostic studies. For predictive studies, hierarchical summary receiver operating characteristic (HSROC) curves with 95\% CIs and predictive regions were graphically visualized. Publication bias was evaluated via Deeks' funnel plot; Deeks' asymmetry test was used to determine the statistical significance of publication bias ${ }^{24}$. Between-study heterogeneity was evaluated using Cochran's Q test with statistical significance at $P<0.05^{25}$; the degree of heterogeneity was based on the Higgins inconsistency index $\left(I^{2}\right)$ where an $I^{2}$ of $0-40 \%$, $30-60 \%, 50-90 \%$, and $75-100 \%$ indicate insignificant, moderate, substantial, and considerable heterogeneity, respectively ${ }^{26}$.

The threshold effect, a positive correlation between sensitivity and the false-positive rate, was visually assessed by the inspection of coupled forest plots of pooled sensitivity and specificity in which an inverted V-shape would indicate a threshold effect. Additionally, Spearman's correlation coefficient of sensitivity and false-positive rates was calculated with a value of $>0.6$ regarded to indicate a threshold effect ${ }^{27}$.

For predictive studies, subgroup bivariate meta-regression analyses were performed to determine the causes of heterogeneity across the studies according to the following covariates: (1) year of publication (after 2016 vs. 
before 2016), (2) study design (retrospective or prospective), (3) follow-up of patients (reported vs. not reported), (4) number of patients (>60 vs. $\leq 60),(5)$ MR tesla (3.0-T vs. $1.5-\mathrm{T}), 6)$ number of b-values used $(\geq 4$ vs. $<4),(7)$ radiologists blinded to outcome (blinded vs. not reported), (8) type of treatment received (concurrent chemoradiation therapy only vs. inclusion of induction or neoadjuvant chemotherapy), (9) proportion of patients with advanced $\mathrm{T}$ stage (T3/4) (>70\% vs. $\leq 70 \%),(10)$ proportion of patients with advanced $\mathrm{N}$ stage $(\mathrm{N} 2 / 3)(>70 \%$ vs. $\leq 70 \%$ ), and (11) region of interest selection (single section vs. volume).

All statistical analyses were performed using STATA version 16.0 (StataCorp, College Station, TX, USA) and $\mathrm{R}$ version 3.6.2 (R Foundation for Statistical Computing, Vienna, Austria). $P<0.05$ was considered statistically significant.

\section{Results}

Literature search. The initial search yielded 186 articles; 56 duplicates were removed. After screening the titles and abstracts, 22 articles were considered potentially eligible after excluding 108 articles for the following reasons: non-English articles $(n=22)$, case reports $(n=9)$, not in the field of interest $(n=56)$, non-original articles (i.e., reviews, letters, editorials, conference abstracts) $(n=18)$, and non-human studies $(n=3)$. After full-text review, nine articles were further excluded because they were not in the field of interest $(n=1)^{28}$, had overlapping study populations $(n=2)^{10,29}$, had insufficient information for the reconstruction of $2 \times 2$ tables $(n=1)^{30}$, insufficient detail of pretreatment $\operatorname{ADC}(n=3)^{31-33}$, or region of interest was on lymph nodes only $(n=2)^{34,35}$. Thirteen original studies were included for qualitative synthesis ${ }^{5,6,8,9,11-19}$. Ultimately, 12 original articles were included for quantitative synthesis ${ }^{5,6,9,11-19}$. Studies with the primary aim of predicting treatment response $e^{5,6,8,9,11,12,14,15,17,19}$ and predicting prognosis of patients $\mathrm{s}^{13,16}$ were evaluated separately in the meta-analysis; one study predicted both treatment response and prognosis ${ }^{18}$ (Fig. 1).

Study characteristics. The total number of patients in all the studies was 2192 (715 for predictive studies $^{5,6,8,9,11,12,14,15,17,19}, 634$ for prognostic studies ${ }^{13,16}$, and 843 patients for the predictive and prognostic study ${ }^{18}$ (Table 1). The number of patients in individual studies ranged from 36-843. The mean age of the patients ranged from 42.2-52 years. Nine studies were retrospective $e^{8,9,11-13,16-19}$, and four were prospective $e^{5,6,14,15}$. All studies originated from China except one from Israe ${ }^{11}$. T stages were reported in all studies while two studies did not report

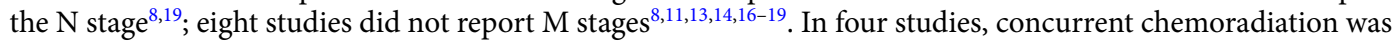
the only treatment modality ${ }^{6,11,14,15}$, whereas other studies used mixed treatment regimens in addition to radiation therapy, including induction chemotherapy ${ }^{5,8,18}$ and neoadjuvant chemotherapy ${ }^{9,12,17}$. The characteristics of the MRI examinations of the included studies are summarized in Table 2.

Quality assessment. For QUADAS-2, all studies showed low risks of bias in flow and timing and patient selection domains; two studies had unclear risks of bias and unclear concerns regarding applicability in the domains of index test and reference standard ${ }^{5,6}$. For QUIPS, one study had a moderate risk of selection bias (Supplemental Figure 1) $)^{13}$.

Predictive performance of DWI-MRI. Among predictive studies investigating treatment response predictions, DWI showed a pooled sensitivity of $87 \%$ (95\% CI 75-94\%) and specificity of 70\% (95\% CI 56-80\%) (Fig. 2). Between-study heterogeneities were present according to the Q test $(P<0.01)$; particularly, the $I^{2}$ statistic revealed substantial heterogeneity in the pooled sensitivity $\left(I^{2}=68.5 \%\right)$ and specificity $\left(I^{2}=92.3 \%\right)$. However, visual assessment of the coupled forest plot showed no threshold effect, and Spearman's correlation coefficient of sensitivity and false-positive rates also indicated the lack of a threshold effect $(-0.48$ [95\% CI $-0.85-0.22])$. In the HSROC curve, a large difference was observed between the areas of $95 \%$ confidence and prediction regions, suggesting between-study heterogeneities (Fig. 3). Based on the slope coefficient of Deeks' funnel plot, the publication bias was low $(P=0.24)$ (Supplementary Figure 2). In three studies that reported the thresholds of ADC changes between treatment ${ }^{8,12,17}$, the sensitivities, specificities, and AUCs for predicting treatment response ranged $64-94 \%, 56.3-72 \%$, and $0.675-0.833$, respectively (Table 2).

Subgroup bivariate meta-regression analyses of predictive studies. Table 3 shows the results of subgroup bivariate meta-regression analyses for determining the causes of between-study heterogeneity. Studies with no heterogeneity $\left(I^{2}=0 \%\right)$ had the following characteristics: (1) inclusion of $>60$ patients; (2) at least four b-values for ADC mapping; (3) $>70 \%$ patients with advanced T stage (T3/4); (4) $\leq 70 \%$ patients with advanced $\mathrm{N}$ stage (N2/3); and (5) region of interest selection as either single section or volume. Prospective studies showed little heterogeneity $\left(I^{2}=3.7 \%\right)$.

Prognostic performance of DWI-MRI. The HRs of OS, LRFS, and DMFS with respect to low ADC were evaluated in three studies ${ }^{13,16,18}$ (Fig. 4). The pooled HRs were 1.42 (95\% CI 1.09-1.85) for OS, 2.31 (95\% CI 1.42-3.74) for LRFS, and 1.35 (95\% CI 1.05-1.74) for DMFS. Because no heterogeneity was present in OS and DMFS and only three studies were included, subgroup analysis was not performed. 


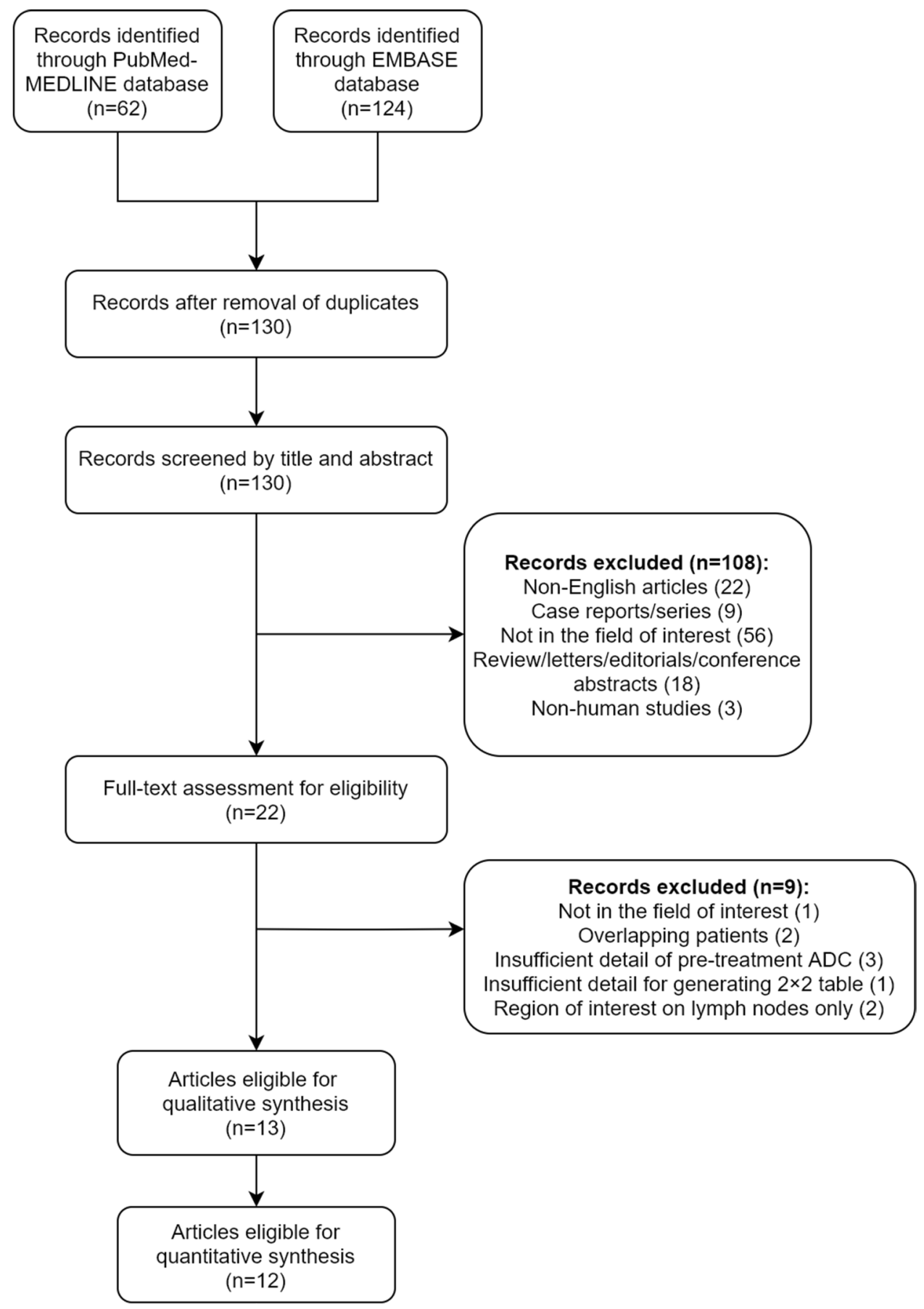

Figure 1. Flow diagram depicting the study eligibility criteria.

\section{Discussion}

This systematic review and meta-analysis assessed the predictive performance of pretreatment ADC for treatment response in patients with NPC. For the prediction of treatment response in NPC, pretreatment ADC showed pooled sensitivity of $87 \%$ and specificity of $70 \%$. However, there was significant between-study heterogeneity regarding pooled sensitivity $\left(I^{2}=68.5 \%\right)$ and specificity $\left(I^{2}=92.3 \%\right)$. In the subgroup bivariate meta-regression analysis to investigate the source of heterogeneity, the studies that included a larger proportion of advanced $\mathrm{T}$ stage $(>70 \%)$, lower proportion of advanced $N$ stage $(\leq 70 \%)$, larger number of patients $(>60)$, used multiple b-values $(\geq 4)$ for ADC mapping, and region of interest selection as either single section or volume had no heterogeneity $\left(I^{2}=0 \%\right)$. Additionally, low pretreatment ADC values were associated with worse OS, LRFS, and DMFS. Therefore, pretreatment ADC had a good predictive performance for treatment response, suggesting its potential role in guiding the treatment strategy in locoregionally advanced NPC. 


\begin{tabular}{|c|c|c|c|c|c|c|c|c|c|c|c|}
\hline $\begin{array}{l}\text { First author } \\
\text { (year of } \\
\text { publication) }\end{array}$ & Affiliation & Study design & $\begin{array}{l}\text { Enrollment } \\
\text { period }\end{array}$ & $\begin{array}{l}\text { No. of } \\
\text { participants }\end{array}$ & Mean age & $\begin{array}{l}\text { Type of } \\
\text { treatment } \\
\text { received }\end{array}$ & Study aim & $\begin{array}{l}\text { Criteria for } \\
\text { treatment } \\
\text { response }\end{array}$ & $\begin{array}{l}\text { Advanced } \\
\text { T-stage } \\
(\mathrm{T} 3 / 4)^{*}\end{array}$ & $\begin{array}{l}\text { Advanced } \\
\mathrm{N} \text {-stage } \\
(\mathrm{N} 2 / 3)^{*}\end{array}$ & $\begin{array}{l}\text { Distant } \\
\text { metastasis } \\
(\text { M1) })^{*}\end{array}$ \\
\hline $\begin{array}{l}\text { Hirchoren } \\
\text { (2019) }\end{array}$ & $\begin{array}{l}\text { Jerusalem, } \\
\text { Israel }\end{array}$ & $\begin{array}{l}\text { Retrospec- } \\
\text { tive }\end{array}$ & $\begin{array}{l}\text { January } \\
\text { 2007-Decem- } \\
\text { ber } 2017\end{array}$ & 58 & 47.7 & CCRT & $\begin{array}{l}\text { Response } \\
\text { prediction }\end{array}$ & NA & $48 \%$ & $88 \%$ & NA \\
\hline $\mathrm{Tu}$ (2019) & $\begin{array}{l}\text { Zhongnan } \\
\text { Hospital } \\
\text { of Wuhan } \\
\text { University, } \\
\text { Wuhan } \\
\text { University, } \\
\text { China }\end{array}$ & $\begin{array}{l}\text { Retrospec- } \\
\text { tive }\end{array}$ & $\begin{array}{l}\text { December } \\
\text { 2015-March } \\
\text { 2017 }\end{array}$ & 36 & 48.5 & $\begin{array}{l}\text { NAC and/or } \\
\text { IMRT }\end{array}$ & $\begin{array}{l}\text { Response } \\
\text { prediction }\end{array}$ & RECIST 1.1 & $67 \%$ & $92 \%$ & $8 \%$ \\
\hline Qin (2018) & $\begin{array}{l}\text { Central } \\
\text { South Uni- } \\
\text { versity and } \\
\text { Hunan Can- } \\
\text { cer Hospital, } \\
\text { China }\end{array}$ & Prospective & $\begin{array}{l}\text { December } \\
\text { 2016-April } \\
2017\end{array}$ & 81 & 48.4 & IC or CCRT & $\begin{array}{l}\text { Response } \\
\text { prediction }\end{array}$ & RECIST 1.1 & $60 \%$ & $90 \%$ & $2 \%$ \\
\hline Yan (2017) & $\begin{array}{l}\text { The First } \\
\text { Affiliated } \\
\text { Hospital of } \\
\text { College of } \\
\text { Medicine, } \\
\text { Zhejiang, } \\
\text { China }\end{array}$ & $\begin{array}{l}\text { Retrospec- } \\
\text { tive }\end{array}$ & NA & 93 & 52 & $\begin{array}{l}\text { IMRT or } \\
\text { CCRT }\end{array}$ & $\begin{array}{l}\text { Survival } \\
\text { prognosis }\end{array}$ & NA & $32 \%$ & $72 \%$ & NA \\
\hline Hou (2016) & $\begin{array}{l}\text { Hunan } \\
\text { Cancer } \\
\text { Hospital and } \\
\text { the Affiliated } \\
\text { Cancer } \\
\text { Hospital } \\
\text { of Xiangya } \\
\text { School of } \\
\text { Medicine, } \\
\text { China }\end{array}$ & Prospective & $\begin{array}{l}\text { April 2014- } \\
\text { May } 2015\end{array}$ & 43 & 48 & CRT & $\begin{array}{l}\text { Response } \\
\text { prediction }\end{array}$ & NA & $95 \%$ & $72 \%$ & $0 \%$ \\
\hline Liu (2015) & $\begin{array}{l}\text { Shandong } \\
\text { Cancer } \\
\text { Hospital and } \\
\text { Institute, } \\
\text { Jinan, China }\end{array}$ & Prospective & $\begin{array}{l}\text { March } \\
\text { 2014-Novem- } \\
\text { ber } 2015\end{array}$ & 42 & 50 & CRT & $\begin{array}{l}\text { Response } \\
\text { prediction }\end{array}$ & RECIST 1.1 & $64 \%$ & $64 \%$ & NA \\
\hline $\begin{array}{l}\text { Xiao-ping } \\
\text { (2015) }\end{array}$ & $\begin{array}{l}\text { The third } \\
\text { Xiangya Hos- } \\
\text { pital, China }\end{array}$ & Prospective & $\begin{array}{l}\text { April } \\
\text { 2014-Decem- } \\
\text { ber 2014 }\end{array}$ & 50 & 48.9 & CRT & $\begin{array}{l}\text { Response } \\
\text { prediction }\end{array}$ & RECIST 1.1 & $78 \%$ & $74 \%$ & $38 \%$ \\
\hline Zhang (2015) & \begin{tabular}{|l|} 
Sun Yat-sen \\
University \\
Cancer \\
Center, \\
China
\end{tabular} & $\begin{array}{l}\text { Retrospec- } \\
\text { tive }\end{array}$ & $\begin{array}{l}\text { November } \\
2010 \text {-May } \\
2012\end{array}$ & 541 & 45.3 & RT or CRT & $\begin{array}{l}\text { Survival } \\
\text { prognosis }\end{array}$ & NA & $66 \%$ & $24 \%$ & NA \\
\hline Chen (2015) & \begin{tabular}{|l|} 
Fujian \\
Provincial \\
Cancer Hos- \\
pital, China
\end{tabular} & $\begin{array}{l}\text { Retrospec- } \\
\text { tive }\end{array}$ & $\begin{array}{l}\text { September } \\
\text { 2013-May } \\
2014\end{array}$ & 59 & 45.2 & $\begin{array}{l}\text { NAC with } \\
\text { IMRT }\end{array}$ & $\begin{array}{l}\text { Response } \\
\text { prediction }\end{array}$ & RECIST 1.1 & $78 \%$ & $81 \%$ & NA \\
\hline Zheng (2013) & \begin{tabular}{|l|} 
Fujian \\
Provincial \\
Cancer Hos- \\
pital, China \\
\end{tabular} & $\begin{array}{l}\text { Retrospec- } \\
\text { tive }\end{array}$ & $\begin{array}{l}\text { January 2007- } \\
\text { June } 2011\end{array}$ & 54 & 42.2 & $\begin{array}{l}\text { NAC and/ } \\
\text { or RT }\end{array}$ & $\begin{array}{l}\text { Response } \\
\text { prediction }\end{array}$ & WHO & $74 \%$ & $76 \%$ & $39 \%$ \\
\hline Huang (2019) & $\begin{array}{l}\text { Sun Yat-sen } \\
\text { University } \\
\text { Cancer } \\
\text { Center, } \\
\text { China }\end{array}$ & $\begin{array}{l}\text { Retrospec- } \\
\text { tive }\end{array}$ & $\begin{array}{l}\text { April 2009- } \\
\text { July } 2014\end{array}$ & 843 & 44 & $\begin{array}{l}\text { CCRT and/ } \\
\text { or IC }\end{array}$ & $\begin{array}{l}\text { Survival } \\
\text { prognosis }\end{array}$ & NA & $86 \%$ & $44 \%$ & NA \\
\hline Law (2016) & $\begin{array}{l}\text { Prince of } \\
\text { Wales Hospi- } \\
\text { tal, China }\end{array}$ & $\begin{array}{l}\text { Retrospec- } \\
\text { tive }\end{array}$ & $\begin{array}{l}\text { March 2004- } \\
\text { April } 2009\end{array}$ & 158 & 50 & RT or CRT & $\begin{array}{l}\text { Response } \\
\text { prediction }\end{array}$ & 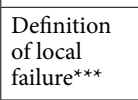 & $53 \%$ & NA & NA \\
\hline $\begin{array}{l}\text { Hong } \\
(2013)^{\star \star}\end{array}$ & $\begin{array}{l}\text { First Affili- } \\
\text { ated Hospital } \\
\text { of Fujian } \\
\text { Medical } \\
\text { University }\end{array}$ & $\begin{array}{l}\text { Retrospec- } \\
\text { tive }\end{array}$ & $\begin{array}{l}\text { April } \\
\text { 2010-Novem- } \\
\text { ber } 2011\end{array}$ & 134 & 47 (median) & $\begin{array}{l}\text { RT (13) or } \\
\text { CRT (121) }\end{array}$ & $\begin{array}{l}\text { Response } \\
\text { prediction }\end{array}$ & WHO & $55 \%$ & NA & NA \\
\hline
\end{tabular}

Table 1. The clinical characteristics of the included studies. CCRT, concurrent chemoradiation therapy; NAC, neoadjuvant chemotherapy; IMRT, intensity-modulated radiation therapy IC, induction chemotherapy; CRT, conformal radiation therapy; RT, radiation therapy; NA, not applicable. ${ }^{*}$ Proportion of patients. ${ }^{* *}$ Not included in quantitative data synthesis. ${ }^{* *}$ Defined as histologically positive or increase in tumor size on imaging or endoscopic examination. 


\begin{tabular}{|c|c|c|c|c|c|c|c|c|c|c|}
\hline $\begin{array}{l}\text { First author } \\
\text { (year of } \\
\text { publication) }\end{array}$ & Manufacturer & MR tesla & TR/TE & $\begin{array}{l}\text { Acquisition } \\
\text { matrix }\end{array}$ & FOV, $\mathbf{m m}^{2}$ & b-value & $\begin{array}{l}\text { ROI selection } \\
\text { criteria }^{*}\end{array}$ & $\begin{array}{l}\text { ROI exclusion } \\
\text { criteria }\end{array}$ & $\begin{array}{l}\text { ADC } \\
\text { thresholds } \\
\left(\times 10^{-3} \mathrm{~mm}^{2} / \mathrm{s}\right)\end{array}$ & $\begin{array}{l}\text { ADC } \\
\text { change } \\
\text { between } \\
\text { treatment } \\
(\%)\end{array}$ \\
\hline $\begin{array}{l}\text { Hirchoren } \\
(2019)\end{array}$ & 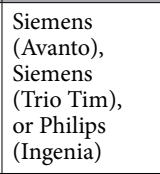 & 1.5 or 3.0 & $4000 / 78$ & $96 \times 96$ & $490 \times 230$ & $0,500,1000$ & Single section & $\begin{array}{l}\text { Cystic and } \\
\text { necrotic } \\
\text { regions }\end{array}$ & 0.805 & NA \\
\hline $\mathrm{Tu}(2019)$ & $\begin{array}{l}\text { Siemens } \\
\text { (Prisma) }\end{array}$ & 3.0 & $3000 / 62.4$ & $44 \times 90$ & 280 & 0,1000 & Volume & $\begin{array}{l}\text { Skull base and } \\
\text { muscle }\end{array}$ & 0.875 & $\begin{array}{l}50 \% \text { (AUC: } \\
0.833)\end{array}$ \\
\hline Qin (2018) & GE (Optima) & 1.5 & $4225 / 106$ & $128 \times 130$ & 200 & $\begin{array}{l}0,50,80,100,150,200,40 \\
0,600,800,1000\end{array}$ & Volume & NA & 0.902 & NA \\
\hline Yan (2017) & $\begin{array}{l}\text { Philips } \\
\text { (Intera) }\end{array}$ & 3.0 & $2947.1 / 43.3$ & $96 \times 96$ & 220 & 0,1500 & Volume & $\begin{array}{l}\text { Cystic and } \\
\text { necrotic } \\
\text { regions }\end{array}$ & 0.72 & NA \\
\hline $\operatorname{Hou}(2016)$ & GE (Optima) & 1.5 & $4225 / 106$ & $128 \times 130$ & $260 \times 260$ & $\begin{array}{l}0,50,80,100,150,200,40 \\
0,600,800,1000\end{array}$ & Volume & \begin{tabular}{|l|} 
Necrotic \\
regions and \\
adjacent \\
structures
\end{tabular} & 0.898 & NA \\
\hline Liu (2015) & $\begin{array}{l}\text { Philips } \\
\text { (Achieva) }\end{array}$ & 3.0 & $10,201.5 / 45$ & NA & 220 & 0,800 & Single section & $\begin{array}{l}\text { Cystic and } \\
\text { necrotic } \\
\text { regions }\end{array}$ & NA & NA \\
\hline $\begin{array}{l}\text { Xiao-ping } \\
(2015)\end{array}$ & GE (Optima) & 1.5 & $4225 / 106$ & $128 \times 130$ & NA & $\begin{array}{l}0,50,80,100,150,200,40 \\
0,600,800,1000\end{array}$ & Volume & $\begin{array}{l}\text { Necrotic } \\
\text { regions and } \\
\text { adjacent } \\
\text { structures }\end{array}$ & 0.879 & NA \\
\hline Zhang (2015) & $\begin{array}{l}\text { Siemens (Trio } \\
\text { Tim) }\end{array}$ & 3.0 & $5100 / 96$ & $192 \times 192$ & 240 & 0,1000 & Volume & $\begin{array}{l}\text { Cystic and } \\
\text { necrotic } \\
\text { regions }\end{array}$ & 0.747 & NA \\
\hline Chen (2015) & $\begin{array}{l}\text { Philips } \\
\text { (Achieva) }\end{array}$ & 3.0 & $4190 / 69$ & 224 & $230 \times 240$ & $0,500,1000,1500$ & Single section & $\begin{array}{l}\text { Necrotic } \\
\text { regions }\end{array}$ & 0.679 & $\begin{array}{l}\text { 51\% (AUC: } \\
0.704)\end{array}$ \\
\hline Zheng (2013) & GE (Signa) & 1.5 & $\begin{array}{l}6000 / \text { the } \\
\text { default mini- } \\
\text { mum }\end{array}$ & $64 \times 64$ & $240 \times 240$ & 0,800 & Volume & NA & 0.916 & NA \\
\hline Huang (2019) & $\begin{array}{l}\text { Siemens (Trio } \\
\text { Tim) }\end{array}$ & 3.0 & $5600 / 93$ & $192 \times 192$ & $240 \times 240$ & 0,1000 & Single section & $\begin{array}{l}\text { Cystic and } \\
\text { necrotic } \\
\text { regions }\end{array}$ & 0.785 & NA \\
\hline Law (2016) & $\begin{array}{l}\text { Philips } \\
\text { (Intera) }\end{array}$ & 1.5 & $2000 / 75$ & $112 \times 112$ & 230 & $0,100,200,300,400,500$ & Volume & NA & 0.55 & NA \\
\hline Hong $(2013)^{* *}$ & GE (Signa) & 1.5 & $\begin{array}{l}6000 / \text { default } \\
\text { minimum }\end{array}$ & $128 \times 128$ & $24 \times 24$ & 0,800 & Single section & NA & NA & $\begin{array}{l}52.7 \%(\mathrm{AUC} \\
0.675)\end{array}$ \\
\hline
\end{tabular}

Table 2. MRI characteristics of the included studies. NA, not applicable; ROI, region of interest; ADC, apparent diffusion coefficient; FOV, field of view; AUC, area under the curve for predicting treatment response. ${ }^{*}$ Single section $=$ the ROI was drawn at the largest cross-sectional area of the tumor; Volume $=$ the mean of all ADC values obtained from all sections involving tumor. ${ }^{* *}$ Not included in quantitative data synthesis.

In the subgroup analysis, no between-study heterogeneity was observed for studies consisting of patients with predominantly advanced T stages. Advanced T stage NPC usually manifests with skull base involvement or intracranial extension. Based on conventional MRI, the evaluation of skull base involvement in NPC has good diagnostic performance ${ }^{4,36}$; however, it has limitations for differentiating tumor involvement from reactive inflammation, leading to difficulties in accurately delineating the primary tumor ${ }^{37}$. In contrast, DWI reflects tissue water diffusivity ${ }^{7}$ with low pretreatment ADC values indicating biological features of tumor cells, such as hypoxia and higher cell density ${ }^{16,38,39}$. DWI performed better than conventional MRI for assessing the tumor microstructure ${ }^{40}$, making it useful for the evaluation of advanced T staged primary NPC. Moreover, because of the large amount of adipose tissue in the clivus, the diagnostic threshold of ADC in the skull base is higher than that of the nasopharyn ${ }^{41}$. Therefore, low ADC NPC values in the skull base (i.e., indicating advanced T stage) may provide a more consistent predictive performance than that in the nasopharynx.

In patients with advanced $\mathrm{N}$ stages, low pretreatment $\mathrm{ADC}$ values of primary tumors provide good predictive performance for detecting treatment response. The ADC value is reportedly directly inversely correlated with histological tumor grade ${ }^{42-44}$. High-grade tumors have higher cellular density with lower ADC values than low-grade tumors ${ }^{45}$. Moreover, patients with poorly differentiated or undifferentiated tumors (i.e. higher cellularity) are more likely to have metastatic cervical lymph nodes than patients with well-differentiated tumors ${ }^{42}$. Therefore, low ADC values in primary tumors may be associated with more frequent metastatic cervical lymph nodes making it a potential poor prognostic factor in NPC. 


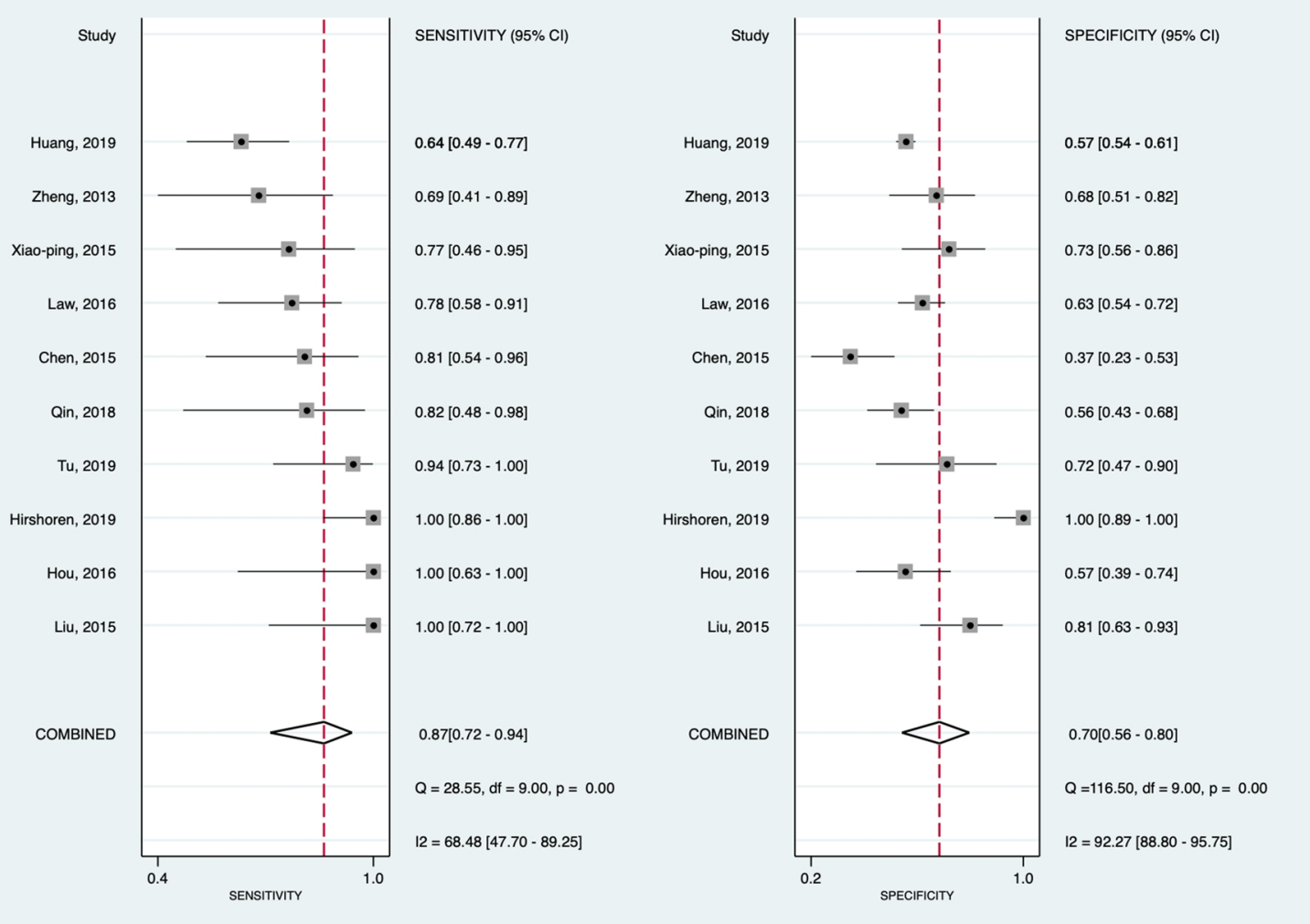

Figure 2. Coupled forest plots illustrating pooled sensitivity and specificity of pretreatment ADC for predicting treatment response in patients with nasopharyngeal carcinoma. Horizontal lines indicate $95 \%$ CIs of each study.

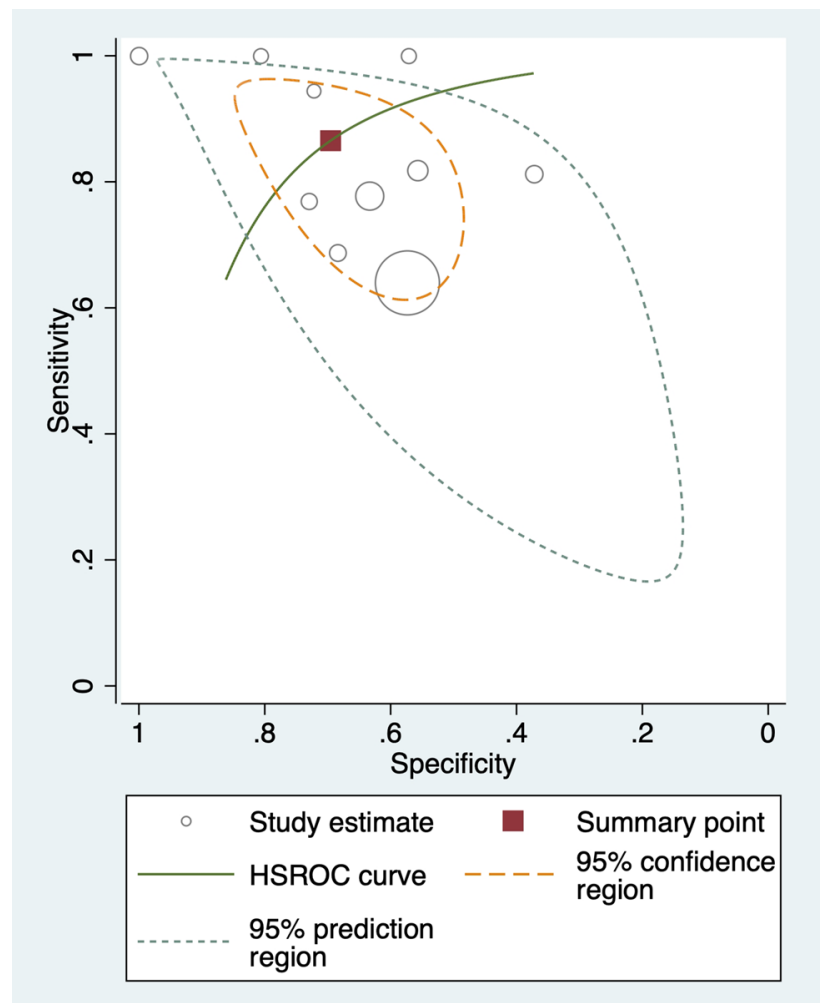

Figure 3. Hierarchical summary receiver operating characteristic (HSROC) curves of pretreatment ADC for predicting treatment response in patients with nasopharyngeal carcinoma. 


\begin{tabular}{|c|c|c|c|c|}
\hline Covariate & No. of studies & Sensitivity (95\% CI) & Specificity $(95 \%$ CI $)$ & $I^{2}$ \\
\hline \multicolumn{5}{|l|}{ Year of publication } \\
\hline$>2016$ & 4 & $86.1 \%(55.4-96.8 \%)$ & $69.8 \%(51.6-83.3 \%)$ & 48.5 \\
\hline$\leq 2016$ & 6 & $76.9 \%(66.7-84.7 \%)$ & $62.9 \%(50.9-73.5 \%)$ & 9.88 \\
\hline \multicolumn{5}{|l|}{ MR tesla } \\
\hline 1.5 & 4 & $83.0 \%(60.0-94.1 \%)$ & $62.3 \%(43.0-78.3 \%)$ & 27.92 \\
\hline 3.0 & 6 & $77.3 \%(67.0-85.1 \%)$ & $62.9 \%(57.4-68.1 \%)$ & 42.28 \\
\hline \multicolumn{5}{|l|}{ Number of patients } \\
\hline$>60$ & 3 & $71.6 \%(57.7-82.3 \%)$ & $58.9 \%(54.8-62.9 \%)$ & 0 \\
\hline$\leq 60$ & 7 & $85.2 \%(71.8-92.8 \%)$ & $68.9 \%(53.1-81.2 \%)$ & 30.2 \\
\hline \multicolumn{5}{|c|}{ Follow-up of patients } \\
\hline Reported & 4 & $81.0 \%(51.5-94.5 \%)$ & $72.8 \%(47.3-88.8 \%)$ & 64.58 \\
\hline Not reported & 6 & $83.8 \%(72.9-90.8 \%)$ & $62.0 \%(48.7-73.7 \%)$ & 4.07 \\
\hline \multicolumn{5}{|c|}{ Number of b-values used } \\
\hline$\geq 4$ & 5 & $78.6 \%(67.8-86.4 \%)$ & $57.4 \%(46.6-67.7 \%)$ & 0 \\
\hline$<4$ & 5 & $87.0 \%(65.1 \%-96.0 \%)$ & $73.8 \%(58.7 \%-84.9 \%)$ & 40.9 \\
\hline \multicolumn{5}{|l|}{ Study design } \\
\hline Retrospective & 6 & $78.7 \%(63.8-88.5 \%)$ & $65.7 \%(49.2-79.1 \%)$ & 52.93 \\
\hline Prospective & 4 & $81.9 \%(66.3-91.2 \%)$ & $65.4 \%(53.0-76.0 \%)$ & 3.66 \\
\hline \multicolumn{5}{|l|}{ Blinded to outcome } \\
\hline Yes & 6 & $85.1 \%(73.7-92.1 \%)$ & $64.4 \%(46.5-79.1 \%)$ & 34.7 \\
\hline Not reported & 4 & $74.3 \%(59.5-85.1 \%)$ & $64.7 \%(55.6-72.8 \%)$ & 28.2 \\
\hline \multicolumn{5}{|l|}{ Treatment } \\
\hline CCRT or RT & 5 & $86.6 \%(69.2-94.9 \%)$ & $72.6 \%(58.3-83.4 \%)$ & 33.3 \\
\hline IC or NAC included & 5 & $74.1 \%(61.2-83.9 \%)$ & $56.4 \%(46.6-65.9 \%)$ & 12.9 \\
\hline \multicolumn{5}{|c|}{ Proportion of advanced T-stage (T3/4) } \\
\hline$>70 \%$ & 5 & $69.3 \%(59.2-77.8 \%)$ & $57.8 \%(46.5-68.4 \%)$ & 0 \\
\hline$\leq 70 \%$ & 5 & $89.6 \%(73.2-96.4 \%)$ & $72.5 \%(57.3-83.8 \%)$ & 36.8 \\
\hline \multicolumn{5}{|c|}{ Proportion of advanced N-stage $(\mathrm{N} 2 / 3)^{\star}$} \\
\hline$>70 \%$ & 7 & $80.2 \%(70.3-87.4 \%)$ & $62.7 \%(50.1-73.7 \%)$ & 35.8 \\
\hline$\leq 70 \%$ & 2 & $84.7 \%(30.3-98.6 \%)$ & $68.4 \%(43.3-86.1 \%)$ & 0 \\
\hline \multicolumn{5}{|l|}{ ROI selection } \\
\hline Single section & 3 & $93.6 \%(69.7-98.9 \%)$ & $80.0 \%(26.8-97.8 \%)$ & 0 \\
\hline Volume & 7 & $74.3 \%(64.7-82.1 \%)$ & $61.1 \%(56.8 \%-65.3 \%)$ & 0 \\
\hline
\end{tabular}

Table 3. Subgroup meta-regression analyses for identifying heterogeneity. CCRT, concurrent chemoradiation therapy; ROI, region of interest; RT, radiation therapy; IC, induction chemotherapy; NAC, neoadjuvant chemotherapy. ${ }^{\star}$ Law et al. did not report $\mathrm{N}$-stage of patients and not included.

Traditionally, ADC is used to reflect tissue water diffusivity; however, it is no longer considered a true diffusion coefficient ${ }^{7}$. The concept of ADC is based on the Einstein equation which was calculated using the Gaussian law assuming water molecules move freely as in a glass of water ${ }^{46}$. However, cancer tissue interacts with cell membranes and surrounding macro- or micro-molecules making it non-Gaussian. To resolve this, intravoxel incoherent motion (IVIM) was introduced to reflect tissue perfusion and blood microcirculation in complex biological environments ${ }^{46}$. Consistent with our findings, tissue perfusion as measured by the bi-exponential fitting of multiple small b-values could presumably provide a more consistent result than the traditional monoexponential fitting of ADC.

This study had some limitations. First, all except one study were published in China which might limit the generalizability of the results. Second, substantial heterogeneity was observed in the pooled specificity of treatment response prediction. However, the potential causes of between-study heterogeneity were explored via subgroup meta-regression. Third, we did not include studies investigating other prognostic factors, including clinical factors and molecular biomarkers. Recently, plasma Epstein-Barr virus DNA has also been proposed as a prognostic factor and screening tool in $\mathrm{NPC}^{47,48}$. Further studies using a combination of imaging techniques and molecular biomarkers for demonstrating treatment response in NPC may show more promising results for early treatment strategies. Fourth, for prognostic studies, subgroup analysis was not performed due to the small number of studies. However, the between-study heterogeneity was not substantial. Finally, the number of included studies was small which might have led to unstable results, particularly for the prognostic studies.

In conclusion, pretreatment ADC value was a good predictor of treatment response in NPC, providing clinically relevant information for developing early treatment strategies. The benefit of multiple b-values for the prediction of treatment response will need to be investigated further. 


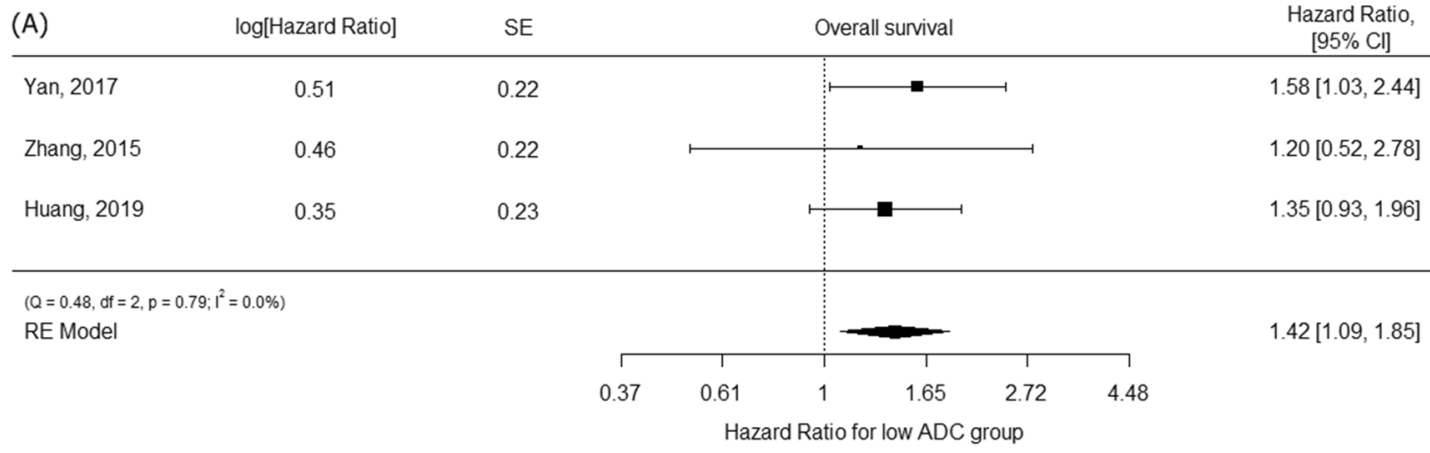

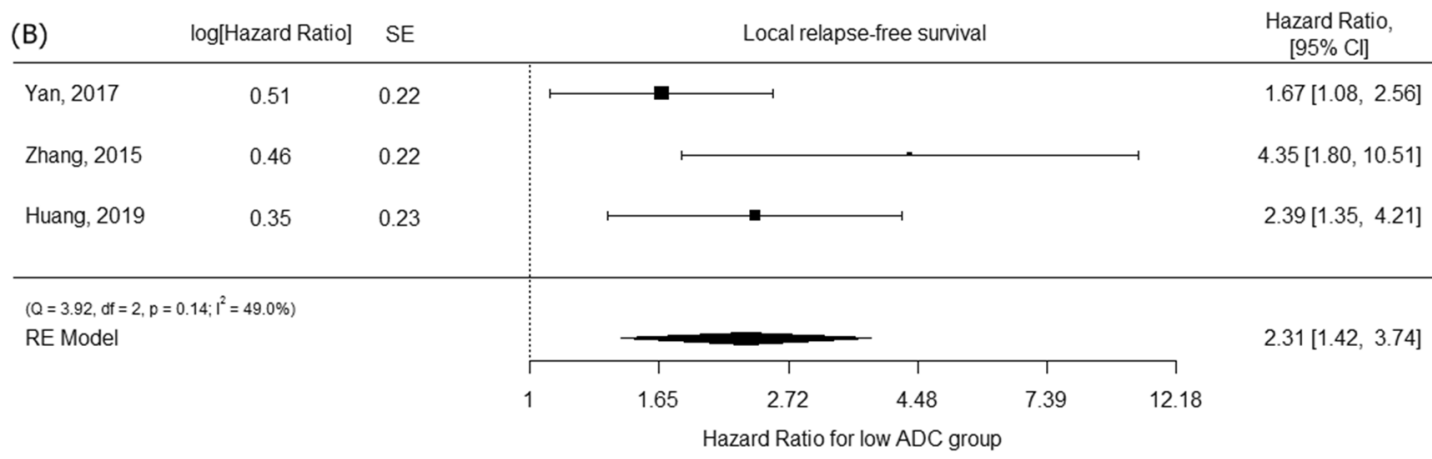

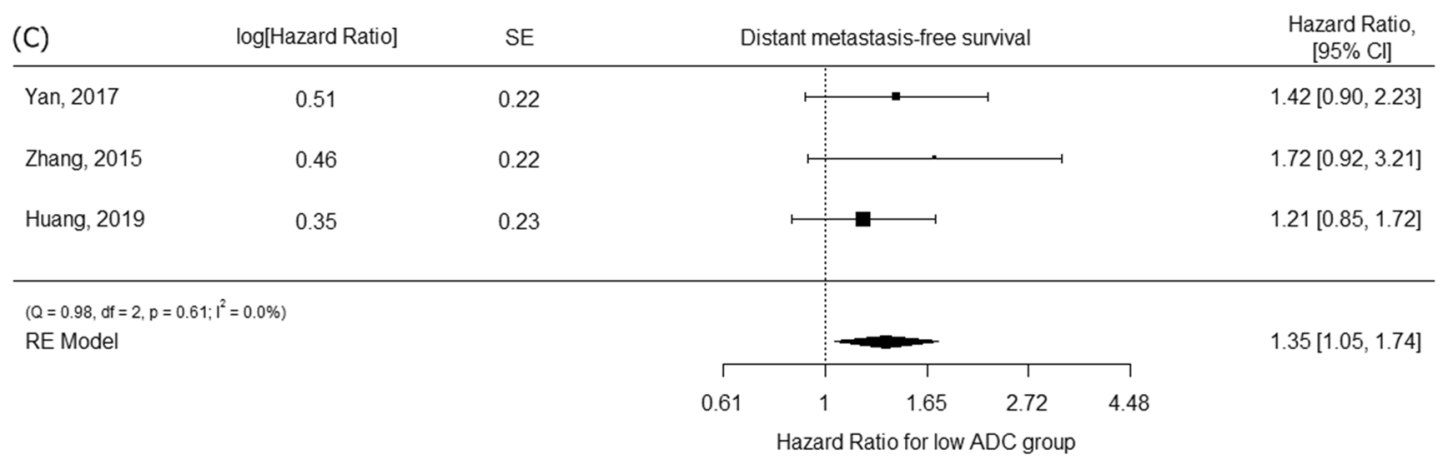

Figure 4. Forest plots for HRs of (A) overall survival, (B) local relapse-free survival, and (C) distant metastasisfree survival.

Received: 21 December 2020; Accepted: 8 September 2021

Published online: 23 September 2021

\section{References}

1. Chen, Y.-P. et al. Nasopharyngeal carcinoma. Lancet 394, 64-80 (2019).

2. Yao, J.-J. et al. Comparing treatment outcomes of concurrent chemoradiotherapy with or without nimotuzumab in patients with locoregionally advanced nasopharyngeal carcinoma. Cancer Biol. Ther. 19, 1102-1107 (2018).

3. Tang, L.-L. et al. Validation of the 8th edition of the UICC/AJCC staging system for nasopharyngeal carcinoma from endemic areas in the intensity-modulated radiotherapy era. J. Natl. Compr. Cancer Netw. 15, 913-919 (2017).

4. Chen, W.-S. et al. Comparison of MRI, CT and 18F-FDG PET/CT in the diagnosis of local and metastatic of nasopharyngeal carcinomas: An updated meta analysis of clinical studies. Am. J. Transl. Res. 8, 4532 (2016).

5. Qin, Y. et al. Predicting chemoradiotherapy response of nasopharyngeal carcinoma using texture features based on intravoxel incoherent motion diffusion-weighted imaging. Medicine (Baltimore) 97, e11676. https://doi.org/10.1097/md.0000000000011676 (2018).

6. Hou, J. et al. Value of intravoxel incoherent motion and dynamic contrast-enhanced MRI for predicting the early and short-term responses to chemoradiotherapy in nasopharyngeal carcinoma. Medicine (Baltimore) 95, e4320. https://doi.org/10.1097/md.00000 00000004320 (2016).

7. Iima, M. \& Le Bihan, D. Clinical intravoxel incoherent motion and diffusion MR imaging: past, present, and future. Radiology 278, 13-32 (2016). 
8. Hong, J. et al. Value of magnetic resonance diffusion-weighted imaging for the prediction of radiosensitivity in nasopharyngeal carcinoma. Otolaryngol. Head Neck Surg. 149, 707-713 (2013).

9. Zheng, D. et al. Early assessment of induction chemotherapy response of nasopharyngeal carcinoma by pretreatment diffusionweighted magnetic resonance imaging. J. Comput. Assist. Tomogr. 37, 673-680 (2013).

10. Chen, Y. et al. Diffusion-weighted magnetic resonance imaging for early response assessment of chemoradiotherapy in patients with nasopharyngeal carcinoma. Magn. Reson. Imaging 32, 630-637 (2014).

11. Hirshoren, N. et al. Diffusion weighted magnetic resonance imaging of pre and post treatment nasopharyngeal carcinoma. Surg. Oncol. 30, 122-125. https://doi.org/10.1016/j.suronc.2019.07.005 (2019).

12. Tu, N. et al. Treatment response prediction of nasopharyngeal carcinoma based on histogram analysis of diffusional kurtosis imaging. AJNR Am J Neuroradiol 40, 326-333. https://doi.org/10.3174/ajnr.A5925 (2019).

13. Yan, D. F. et al. The prognostic value of pretreatment tumor apparent diffusion coefficient values in nasopharyngeal carcinoma. BMC Cancer 17, 678. https://doi.org/10.1186/s12885-017-3658-x (2017).

14. Liu, J. et al. Use of texture analysis based on contrast-enhanced MRI to predict treatment response to chemoradiotherapy in nasopharyngeal carcinoma. J. Magn. Reson. Imaging 44, 445-455. https://doi.org/10.1002/jmri.25156 (2016).

15. Xiao-ping, Y. et al. Intravoxel incoherent motion MRI for predicting early response to induction chemotherapy and chemoradiotherapy in patients with nasopharyngeal carcinoma. J. Magn. Reson. Imaging 43, 1179-1190. https://doi.org/10.1002/jmri.25075 (2016).

16. Zhang, Y. et al. Prognostic value of the primary lesion apparent diffusion coefficient (ADC) in nasopharyngeal carcinoma: A retrospective study of 541 cases. Sci. Rep. 5, 12242. https://doi.org/10.1038/srep12242 (2015).

17. Chen, Y. et al. Diffusion kurtosis imaging predicts neoadjuvant chemotherapy responses within 4 days in advanced nasopharyngeal carcinoma patients. J. Magn. Reson. Imaging 42, 1354-1361. https://doi.org/10.1002/jmri.24910 (2015).

18. Huang, T. X. et al. The primary lesion apparent diffusion coefficient is a prognostic factor for locoregionally advanced nasopharyngeal carcinoma: A retrospective study. BMC Cancer https://doi.org/10.1186/s12885-019-5684-3 (2019).

19. Law, B. K. H. et al. Diffusion-weighted imaging of nasopharyngeal carcinoma: Can pretreatment DWI predict local failure based on long-term outcome?. Am. J. Neuroradiol. 37, 1706-1712. https://doi.org/10.3174/ajnr.A4792 (2016).

20. Moher, D., Liberati, A., Tetzlaff, J. \& Altman, D. G. Preferred reporting items for systematic reviews and meta-analyses: The PRISMA statement. Ann. Intern. Med. 151, 264-269 (2009).

21. Oldenhuis, C., Oosting, S., Gietema, J. \& De Vries, E. Prognostic versus predictive value of biomarkers in oncology. Eur. J. Cancer 44, 946-953 (2008).

22. Whiting, P. F. et al. QUADAS-2: A revised tool for the quality assessment of diagnostic accuracy studies. Ann. Intern. Med. 155, 529-536 (2011).

23. Fan, W. J. et al. Diffusion-weighted imaging as a follow-up modality for evaluation of major salivary gland function in nasopharyngeal carcinoma patients: A preliminary study. Strahlenther Onkol. https://doi.org/10.1007/s00066-020-01580-5 (2020).

24. Deeks, J. J., Macaskill, P. \& Irwig, L. The performance of tests of publication bias and other sample size effects in systematic reviews of diagnostic test accuracy was assessed. J. Clin. Epidemiol. 58, 882-893 (2005).

25. Hoaglin, D. C. Misunderstandings about Q and 'Cochran's Q test'in meta-analysis. Stat. Med. 35, 485-495 (2016).

26. Kim, K. W., Lee, J., Choi, S. H., Huh, J. \& Park, S. H. Systematic review and meta-analysis of studies evaluating diagnostic test accuracy: A practical review for clinical researchers-Part I. General guidance and tips. Korean J. Radiol. 16, 1175-1187 (2015).

27. Devillé, W. L. et al. Conducting systematic reviews of diagnostic studies: Didactic guidelines. BMC Med. Res. Methodol. 2, 9 (2002).

28. Huang, W. et al. Potential value of non-echo-planar diffusion-weighted imaging of the nasopharynx: A primary study for differential diagnosis between recurrent nasopharyngeal carcinoma and post-chemoradiation fibrosis. Acta Radiol. 60, 1265-1272. https://doi.org/10.1177/0284185118822635 (2019).

29. Zhang, G. Y. et al. Pretreatment diffusion-weighted MRI can predict the response to neoadjuvant chemotherapy in patients with nasopharyngeal carcinoma. Biomed. Res. Int. 2015, 307943. https://doi.org/10.1155/2015/307943 (2015).

30. Huang, W. Y. et al. In vivo imaging markers for prediction of radiotherapy response in patients with nasopharyngeal carcinoma: RESOLVE DWI versus DKI. Sci. Rep. 8, 15861. https://doi.org/10.1038/s41598-018-34072-9 (2018).

31. Xiao, Y. et al. Longitudinal assessment of intravoxel incoherent motion diffusion weighted imaging in evaluating the radio-sensitivity of nasopharyngeal carcinoma treated with intensity-modulated radiation therapy. Cancer Res. Treat. 51, 345-356. https:// doi.org/10.4143/crt.2018.089 (2019).

32. Xiao, Y. et al. Intravoxel incoherent motion-magnetic resonance imaging as an early predictor of treatment response to neoadjuvant chemotherapy in locoregionally advanced nasopharyngeal carcinoma. Medicine (Baltimore) 94, 973. https://doi.org/10.1097/md. 0000000000000973 (2015).

33. Qamar, S. et al. Pre-treatment intravoxel incoherent motion diffusion-weighted imaging predicts treatment outcome in nasopharyngeal carcinoma. Eur. J. Radiol. 129, 109127. https://doi.org/10.1016/j.ejrad.2020.109127 (2020).

34. Lu, L., Li, Y. \& Li, W. The role of intravoxel incoherent motion MRI in predicting early treatment response to chemoradiation for metastatic lymph nodes in nasopharyngeal carcinoma. Adv. Ther. 33, 1158-1168. https://doi.org/10.1007/s12325-016-0352-3 (2016).

35. Hu, Y. et al. Predictive value of diffusion-weighted magnetic resonance imaging for cervical lymph node metastasis in nasopharyngeal carcinoma after chemoradiotherapy. Int. J. Clin. Exp. Med. 9, 22739-22749 (2016).

36. Chung, N. N., Ting, L. L., Hsu, W. C., Lui, L. T. \& Wang, P. M. Impact of magnetic resonance imaging versus CT on nasopharyngeal carcinoma: Primary tumor target delineation for radiotherapy. Head Neck 26, 241-246 (2004).

37. Altun, M., Tenekeci, N., Kaytan, E. \& Meral, R. Locally advanced nasopharyngeal carcinoma: computed tomography findings, clinical evaluation, and treatment outcome*. Int. J. Radiat. Oncol. ${ }^{*}$ Biol. ${ }^{*}$ Phys. 47, 401-404 (2000).

38. Ni, X. et al. Diffusion-weighted magnetic resonance imaging in predicting the radiosensitivity of cervical cancer. Int. J. Clin. Exp. Med. 8, 13836 (2015).

39. Larocque, M. P., Syme, A., Allalunis-Turner, J. \& Fallone, B. G. ADC response to radiation therapy correlates with induced changes in radiosensitivity. Med. Phys. 37, 3855-3861 (2010).

40. Zheng, X. et al. Diffusion kurtosis imaging and tumour microstructure for monitoring response to radiotherapy in human nasopharyngeal carcinoma xenografts. Jpn. J. Clin. Oncol. https://doi.org/10.1093/jjco/hyaa002 (2020).

41. Ginat, D. T., Mangla, R., Yeaney, G., Johnson, M. \& Ekholm, S. Diffusion-weighted imaging for differentiating benign from malignant skull lesions and correlation with cell density. Am. J. Roentgenol. 198, W597-W601 (2012).

42. Razek, A. A. K. A. \& Kamal, E. Nasopharyngeal carcinoma: correlation of apparent diffusion coefficient value with prognostic parameters. Radiol. Med. (Torino) 118, 534-539 (2013).

43. Ichikawa, Y., Sumi, M., Sasaki, M., Sumi, T. \& Nakamura, T. Efficacy of diffusion-weighted imaging for the differentiation between lymphomas and carcinomas of the nasopharynx and oropharynx: Correlations of apparent diffusion coefficients and histologic features. Am. J. Neuroradiol. 33, 761-766 (2012).

44. Razek, A. A., Elkhamary, S., Al-Mesfer, S. \& Alkatan, H. Correlation of apparent diffusion coefficient at 3T with prognostic parameters of retinoblastoma. Am. J. Neuroradiol. 33, 944-948 (2012).

45. Razek, A. A. K. A. Diffusion-weighted magnetic resonance imaging of head and neck. J. Comput. Assist. Tomogr. 34, 808-815 (2010). 
46. Le Bihan, D. et al. Separation of diffusion and perfusion in intravoxel incoherent motion MR imaging. Radiology 168, 497-505 (1988).

47. Chan, K. A. et al. Analysis of plasma Epstein-Barr virus DNA to screen for nasopharyngeal cancer. N. Engl. J. Med. 377, 513-522 (2017).

48. Tang, L.-Q. et al. Establishment and validation of prognostic nomograms for endemic nasopharyngeal carcinoma. JNCI J. Natl. Cancer Inst. 108, djv291 (2016).

\section{Author contributions}

M.K.L. contributed to acquisition of data, interpreted the data carried out for the meta-analysis, and drafted the manuscript. Y.C. contributed the design of the study, data analysis, statistical analysis of the study, and participated to draft the manuscript. S.J. contributed to revise the article and helped to draft the manuscript. All authors read and approved the final manuscript.

\section{Funding}

This research was supported by Basic Science Research Program through the National Research Foundation of Korea (NRF) funded by the Ministry of Education (2021R1I1A1A01040285).

\section{Competing interests}

The authors declare no competing interests.

\section{Additional information}

Supplementary Information The online version contains supplementary material available at https://doi.org/ 10.1038/s41598-021-98508-5.

Correspondence and requests for materials should be addressed to Y.C.

Reprints and permissions information is available at www.nature.com/reprints.

Publisher's note Springer Nature remains neutral with regard to jurisdictional claims in published maps and institutional affiliations.

(c) (i) Open Access This article is licensed under a Creative Commons Attribution 4.0 International License, which permits use, sharing, adaptation, distribution and reproduction in any medium or format, as long as you give appropriate credit to the original author(s) and the source, provide a link to the Creative Commons licence, and indicate if changes were made. The images or other third party material in this article are included in the article's Creative Commons licence, unless indicated otherwise in a credit line to the material. If material is not included in the article's Creative Commons licence and your intended use is not permitted by statutory regulation or exceeds the permitted use, you will need to obtain permission directly from the copyright holder. To view a copy of this licence, visit http://creativecommons.org/licenses/by/4.0/.

(C) The Author(s) 2021 